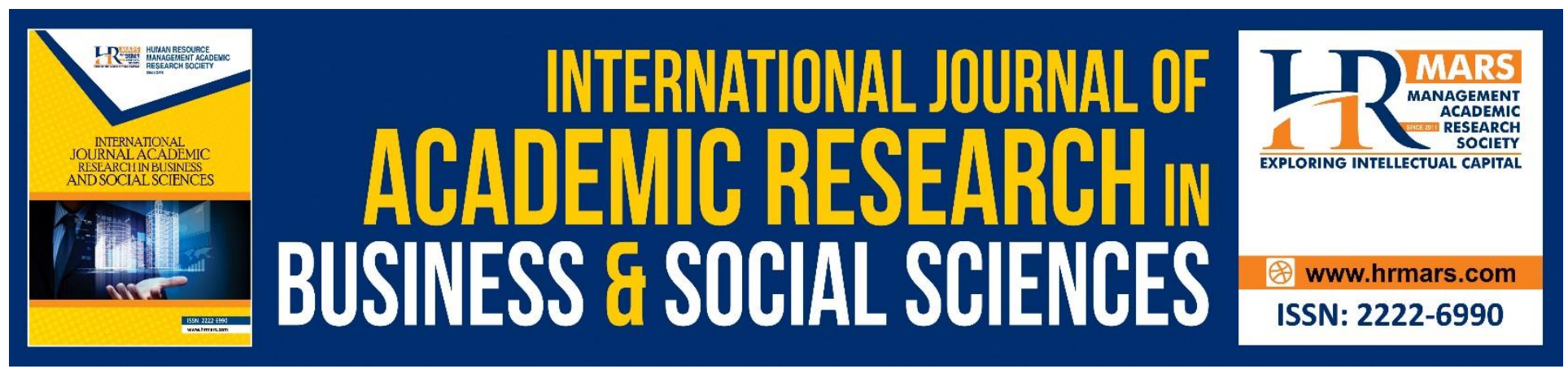

\title{
The Effect of News Framing the Policy Implementation Good Services and Tax (GST) Towards Audiences Expression in Malaysia
}

Julia Wirza Mohd Zawawi \& Chang Peng Kee

To Link this Article: http://dx.doi.org/10.6007/IJARBSS/v10-i15/8250

DOI:10.6007/IJARBSS/v10-i15/8250

Received: 08 September 2020, Revised: 13 October 2020, Accepted: 16 November 2020

Published Online: 30 November 2020

In-Text Citation: (Zawawi \& Kee, 2020)

To Cite this Article: Zawawi, J. W. M., \& Kee, C. P. (2020). The Effect of News Framing the Policy Implementation Good Services and Tax (Gst) Towards Audiences Expression in Malaysia. International Journal of Academic Research in Business and Social Sciences, 10(15), 292-304.

\section{Copyright: @ 2020 The Author(s)}

Published by Human Resource Management Academic Research Society (www.hrmars.com)

This article is published under the Creative Commons Attribution (CCBY 4.0) license. Anyone may reproduce, distribute, translate and create derivative works of this article (for both commercial and non-commercial purposes), subject to full attribution to the original publication and authors. The full terms of this license may be seen

at: http://creativecommons.org/licences/by/4.0/legalcode

Special Issue: Youth and Community Wellbeing: Issues, Challenges and Opportunities for Empowerment V1, 2020, Pg. 292 - 304

Full Terms \& Conditions of access and use can be found at http://hrmars.com/index.php/pages/detail/publication-ethics 


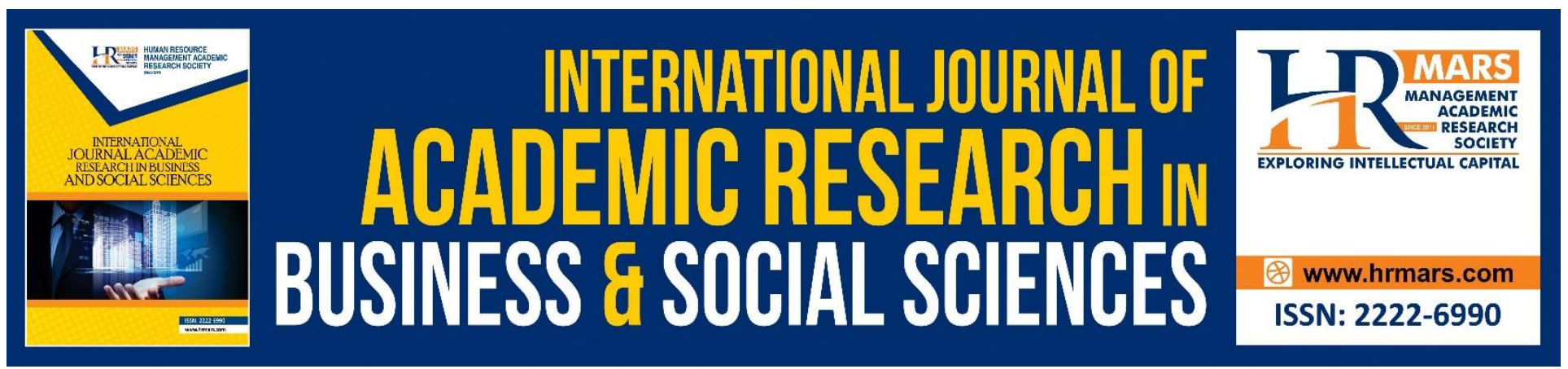

\title{
The Effect of News Framing the Policy Implementation Good Services and Tax (Gst) Towards Audiences Expression in Malaysia
}

\author{
Julia Wirza Mohd Zawawi ${ }^{1,2}$ \& Chang Peng Kee ${ }^{3}$ \\ ${ }^{1}$ Institute for Social Science Studies, Universiti Putra Malaysia, 43400 Serdang, Selangor \\ ${ }^{2}$ Department of Communication, Faculty of Modern Languages and Communication, Universiti \\ Putra Malaysia, 43400 Serdang, Selangor \\ ${ }^{3}$ Centre For Research in Media and Communication, Universiti Kebangsaan Malaysia, 43000 Bangi, \\ Selangor \\ Email: wirza@upm.edu.my, chang@ukm.edu.my
}

\begin{abstract}
The implementation of government policy as an example of GST is one of the policies introduced and implemented in Malaysia within a short period of time between 2015 and 2018 only. Policy implementation by the government is taken seriously as it involves the community and they have the right to know and understand the policy before implementation. One of the drastic and dominant initiatives taken by the government is to use media as mediation. The study aims to identify the effectiveness of news framing from the GST government policy on the true expression of the audience. The experimental approach was using 165 participants and some forms of GST news were designed to test the effectiveness of the expression and the responses of the audience. The findings suggest that Malaysian society does not give extreme response to the news frames published by the mass media.
\end{abstract}

Keywords: Framing, Expression, Frame Setting, Good Services and Tax

\section{Introduction}

Announcement of the 6th Prime Minister of Malaysia, Datuk Seri Najib Tun Abdul Razak through a budget presentation in 2013, the government announced the implementation of the new Goods and Services Tax (GST) policy and replace of the Sales and Tax Services (SST).

GST was originally known as Value Added Tax (VAT) is a general consumer tax that is designed to impose on all commercial activities whether involved in the production of goods or services (Schenk \& Oldman, 2007). Whereas based on the European Commission, VAT refers to consumerism tax based on added value concepts. 
INTERNATIONAL JOURNAL OF ACADEMIC RESEARCH IN BUSINESS AND SOCIAL SCIENCES

Vol. 10, No. 15, Youth and Community Wellbeing: Issues, Challenges and Opportunities for Empowerment V1. 2020, E-ISSN: 2222-6990 @ 2020 HRMARS

Implementation and change of policies such as the GST is a plan that must be carried out carefully by the government not to burden the public. Research has to be carried out by the government continuously to identify the responses of the audience. This is because the successful implementation of a policy depends on the operational of political system and can guarantee development (Hussain, 2000). Especially when involving issues of taxation and finance. Level of knowledge about the issue of taxation is a complex and not all persons can understand taxation issues easily. In the case, of such media played a very important role in shaping the right and perfect news issues to deliver to audience.

\section{Problem Statement and Research Objective}

News portray related to the implementation and changes of policies by government through media whether mass media or new media gives an overview of the diversity to audience. McClure, White and Sibley (2009) give an impression that every message content delivered by news issues contains different feedback. In other words, the effects of media issues portray by the media are different to each individual. Similarly, with this GST issue, its implementation provides various assumptions and reactions from the community either in positive or negative form. Hence, this study has some of the key objectives:

i. To identify the effect of portraying GST implementation news towards audience expression. ii. To compare the level of knowledge (pre-test) with an audience (post-test) expression.

\section{Literature Review}

\section{Media and Politics}

These two elements play a dominant role in political communication comprising politicians, media practitioners and audiences. In order to gain support for policy implementation, politicians sought to gain the attention of media practitioners (McNair, 2007). Media practitioners choose a particular approach to framing news issues that are received with many other factors in consideration. And then the audience accepted the news through the media. Audiences can also influence the display of the media by expressing their importance in some issues. In other words, these three elements affect each other through the communication process (Cartee, 2007).

As we entered into an era of unprecedented interconnectivity, we find that information is able to move at equally unprecedented rates among large populaces. This has severe implications on the political process and new age media such as Facebook, Twitter, and Whatsapp to name a few have a role to play in ensuring that established institutional processes such as the electoral process are improved and not disrupted (Nadiah \& Maheran, 2019).

. To ensure effectiveness policy implementation, politicians need to use effective tactics and strategies. Sanders (2009) explains that effective strategies from politicians to implement policy through the media should contain clear content, interesting, paradox and recurrent strategy campaign. The development of today's communication technology has led politicians to conquer the media. Information sharing becomes faster and easier, give pressure on politicians to seek publicity in a convenient way. Limited news space ongoing effort to create illusions via the news coupled with 
INTERNATIONAL JOURNAL OF ACADEMIC RESEARCH IN BUSINESS AND SOCIAL SCIENCES

Vol. 10, No. 15, Youth and Community Wellbeing: Issues, Challenges and Opportunities for Empowerment V1. 2020, E-ISSN: 2222-6990 @ 2020 HRMARS

reporters that bias to a more dramatic form of news, in the form of private and simple (Bennet, 2007). The difficulty to get the communications space has prompted politicians to try to new communication style to enable the dependence on media and communication specialist (Cook, 2007).

\section{Politics and GST}

GST issues though has now been removed and returned to the tax system, which is the original SST, it continues to be a hot issue and discussed by the community. This is because when discussing on GST it is closely related with policy implementation. And the implementation of a policy by the government is not something easy. Have to be agreed to by the ministers and receive positive feedback from audiences. Not only the implementation of GST but other policies too, its implementation should get consensus or known as political will. The implementation of a policy starting with political will from ministers so that the responsibilities entrusted can be carried out effectively.

Political participation is very vital in order to strengthen the application of a democratic system. Without people's involvement, it is difficult for a country to be called democratic (Nadiah \& Maheran, 2019). Sanders (2009) explained that the politician is among the most dominant and influential to control and strategies used for the information. This means that, when implementing a policy which involves politicians, they are among the role determine the flow of information to spread among audience.

\section{Media and GST}

Before implementing policy, a key matters that need to be addressed by the government is giving the understanding and knowledge to the audience. If before this attempt by the government to implement the GST was not successful due to the knowledge society that is still low. However after the announcement during the presentation of the budget in 2013, the government use a variety of approaches to give understanding to the audience. Mass media such as television, radio, newspapers, billboards and social media is one of the intermediate medium used by the government a few months before its implementation on 1 April 2015. This is one of reason to provide a better understanding and knowledge of prior to implementation of the policy. High level of knowledge of a country's society prior to implementation of policies is important for ensuring the receipt as a whole.

In accordance with what is being said by Idris and Yussof (2009), which is to ensure that effective policies and strategies by the government is to create a first class community. And community groups need to be educated so that they can know and understand the opportunities that are available for the self, family, community and country development.

\section{Theoretical Framework}

\section{Framing Theory}

This study uses the framing theory as a theoritical framework. The studies of news framing across multiple fields and not only focused on communication exclusively. The concept of the frame based on Gamson and Modigliani (1989) refers to a repeating pattern of cognition interpretation of delivery, selection and emphasis. The frame is also a form of interpretative package that gives 
INTERNATIONAL JOURNAL OF ACADEMIC RESEARCH IN BUSINESS AND SOCIAL SCIENCES

Vol. 10, No. 15, Youth and Community Wellbeing: Issues, Challenges and Opportunities for Empowerment V1. 2020, E-ISSN: 2222-6990 @ 2020 HRMARS

meaning to the display of an issue. And despite the issues implied a form of key management to ensure concerning relevant issues.

Klar et al. (2013) describes the concept of the frame as a form of individual perception of a situation. The frames will reveal what they think of as relevant, as alternative to understand something of the situation.

However, through this study using the model used by de Vreese (2005). The framing integration process model introduce two key elements which is frame building and frame setting. These both factors is seen as a key factors in the news framing process. In the frame building, there are two factors that influence the formation news which are internal and external factors. Internal factors are composed of the editorial and journalists. While external factors that influence the formation of elite groups such as news is a politician, a corporate member or owner of a media organization itself.

Framing effect

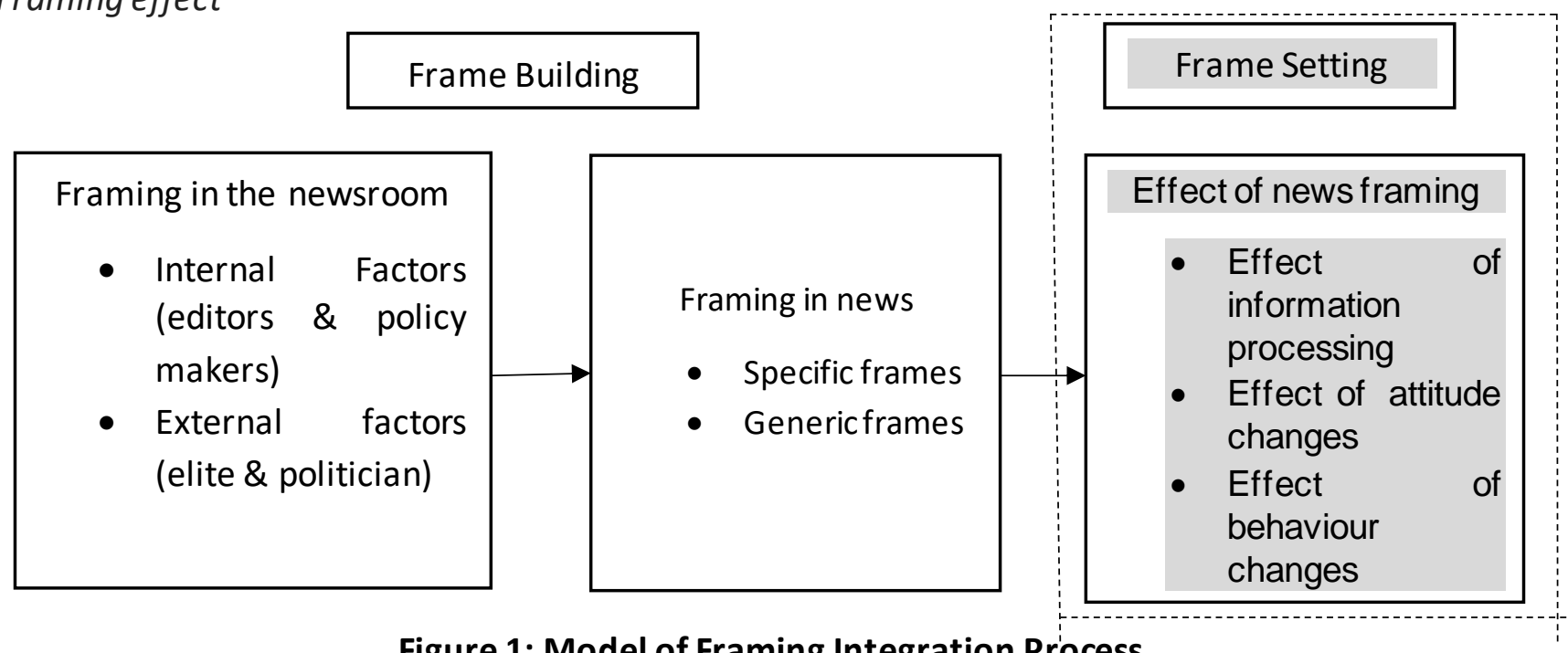

Figure 1: Model of Framing Integration Process

Based on the model introduced by Vreese (2005) as in Figure 1 above shows that through this study, focusing on the effect of news framing. The effects of framing is a studies of the effect of the media presented by studying the effects of news frames to audience. De Vreese (2005) explains the effect of framing has three main effects which is effect of information processing, the effects of attitude changes and behavioural effects.

The studies of framing effect has relevance to psychology that focusing the process of individual schemata exposed by news in media. Framing effects occur when individual processing schemata messages that are different and finally give a different response (McClure, et al., 2009).

\section{Expression}

Process response received through messages from the media was named as expression. Messages received through schemata, processed and subsequently produce a reaction of expression. 
Boyle et al. (2006) explain that the individual explain the expression as an action to express an opinion. This action also was described as a way to maintain an active community involvement.

Boyle et al. (2006) explains that through a study conducted there are seven stages in expression such as (i) discuss issues dealt with family members (ii) issued an opinion on the issue is being said to others (iii) send comments to the editor/newspaper about the issue that is addressed (iv) contacting government officials to give a comment about an issue ( $v$ ) obtain feedback from government officials against an issue (vi) attending the forum/public discussions related to an issue (vii) attend any rally (rally) as a sign of protest.

\section{Methodology}

Experimental approach used as a research methodology through this research. There are 165 participants involve in this experiment consisting of three local authority which is Majlis Perbandaran Kajang (MPKj), Majlis Bandaraya Shah Alam (MBSA) and Majlis Daerah Kuala Langat (MDKL). The selection of the local authority as a participant in experiment relevant in view of the local authority as an intermediate agent between state and society.

In addition, relationship local authorities with government and communities are form of positive relationship and government policy delivery is seen influencing demanding for community development (Singarevelloo \& vadeveloo, 2013)

This research using random sampling. It is used through division participant of experimental group. Each participant is divided into groups by number cards, to ensure division of number also done by random. Justification this random sampling, to putting same features depends on the opportunities rather on researcher. This also ensure the sample selected is not through the process of bias.

The news frames used as independent variables are divided into three forms which is pro, cons and neutral frame. Researcher replicate the news frames based on transcript of Rang Undangundang GST dated April 2014. Justification the researcher replicate and design on news frame also to ensure each news segregated according to theme pro, cons and neutral.

\section{Research Framework}

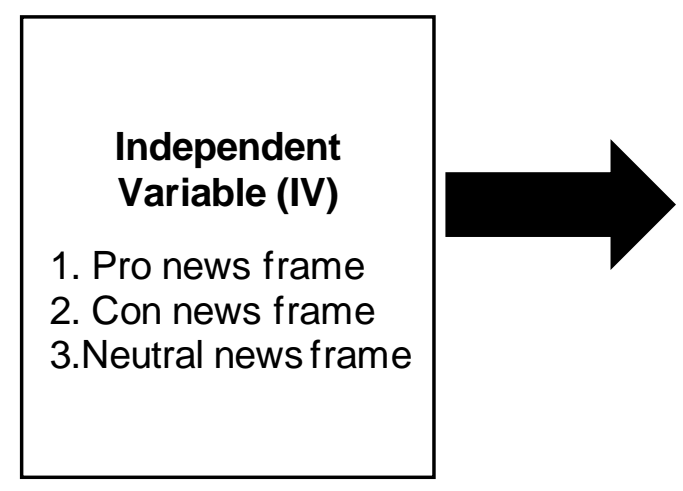

\section{Dependent Variable (DV)}

\section{Expression}

L1. Discuss with family members

L2. Heard on issues to others

L3. Send comments to editor/newspaper about an issues

L4. Attended any talk held related an issues

L5. Get feedback from government officials about an issues

L6. Attending the forum/public discussion related to an issues

L7. Attending any rally (as a protest) related to an issues

Figure 2: Research Framework 
INTERNATIONAL JOURNAL OF ACADEMIC RESEARCH IN BUSINESS AND SOCIAL SCIENCES

Vol. 10, No. 15, Youth and Community Wellbeing: Issues, Challenges and Opportunities for Empowerment V1. 2020, E-ISSN: 2222-6990 @) 2020 HRMARS

To verify the validity and reliability of each instrument study conducted, several languages and psychology experts referred to as research closely linked to psychology. Some improvements were also conducted to ensure the results more relevant and accurate. Cronbach Alpha result used to measure the reliability of instrument which is 0.889 . A high value to form the dependent variable that is expression. Manipulation check also carried out to ensure each news frames provided manipulated based on pro, cons and neutral.

\section{Research Design \& Procedure}

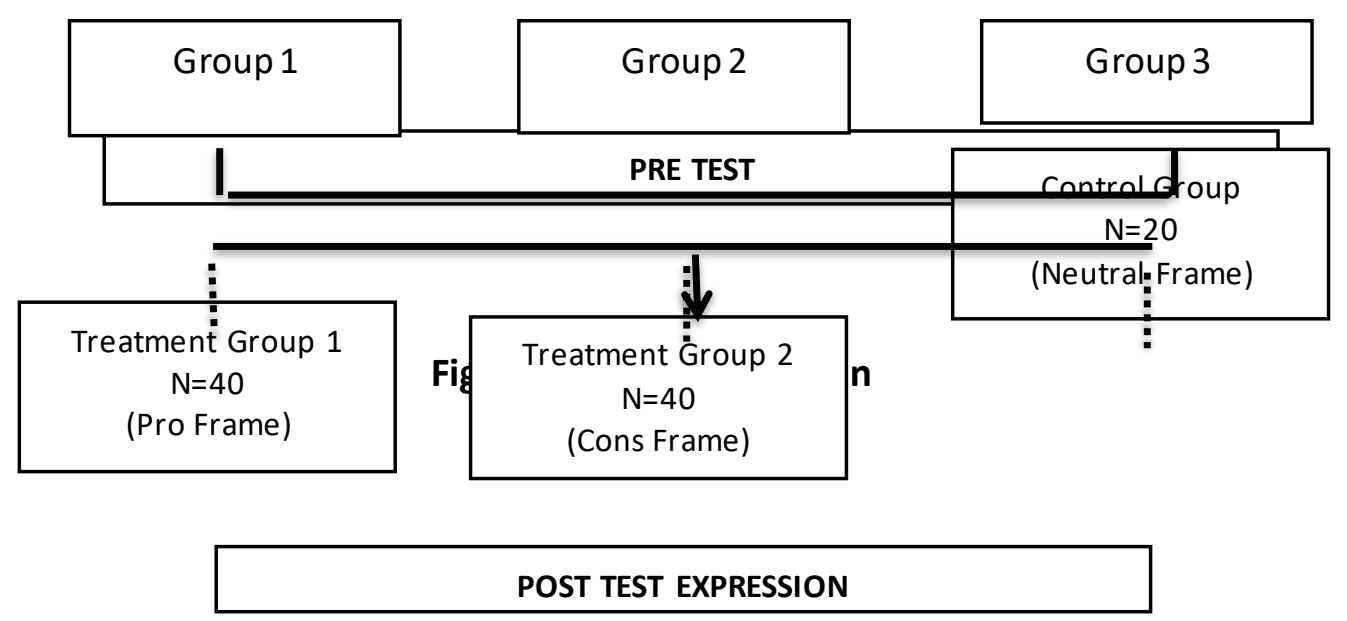

Pre-Test

This study divided into two procedures which are pre test and post test. At the pre test stage, a set of questions given to find out the level of knowledge and understanding of the participants of GST. For the pre test consist 17 item questions. The question contained demographic of respondent and a few question about GST general knowledge. The level of knowledge of the participants measured using nominal scale and divided into two which is "yes" or "no".

\section{Post-Test}

For the post test, participant were divided into three groups which is Treatment Group 1, Treatment Group 2 and Control Group. Treatment Group 1 exposed to pro news frame, Treatment Group 2 exposed to cons news frame and Control Group were exposed to neutral frame. A set of question distributed to measure expression reaction towards the frames. 
INTERNATIONAL JOURNAL OF ACADEMIC RESEARCH IN BUSINESS AND SOCIAL SCIENCES

Vol. 10, No. 15, Youth and Community Wellbeing: Issues, Challenges and Opportunities for Empowerment V1. 2020, E-ISSN: 2222-6990 @) 2020 HRMARS

Demography Profile

\section{Result}

Table 1: Demography profile of participant

\begin{tabular}{|c|c|c|c|c|}
\hline Category & Frequency & $\begin{array}{l}\text { Percentage } \\
(\%)\end{array}$ & $M$ & SD \\
\hline \multicolumn{5}{|l|}{ Gender } \\
\hline Male & 119 & 72.1 & & \\
\hline Female & 46 & 21.9 & & \\
\hline Total & 165 & 100 & & \\
\hline \multicolumn{5}{|l|}{ Age } \\
\hline 20 until 29 tahun & 48 & 29.10 & & \\
\hline 30 until 39 tahun & 88 & 53.33 & 33.67 & 7.82 \\
\hline 40 until 49 tahun & 22 & 13.33 & & \\
\hline 50 until 59 tahun & 7 & 4.24 & & \\
\hline Total & 165 & 100 & & \\
\hline \multicolumn{5}{|l|}{ Location } \\
\hline Urban & 97 & 58.8 & & \\
\hline Rural & 68 & 41.2 & & \\
\hline Total & 165 & 100 & & \\
\hline \multicolumn{5}{|l|}{ Income } \\
\hline RM500-RM900 & 7 & 4.2 & & \\
\hline RM901-RM1500 & 51 & 30.9 & & \\
\hline RM1501-RM2500 & 78 & 47.3 & & \\
\hline$>$ RM2500 & 29 & 17.6 & & \\
\hline Total & 165 & 100 & & \\
\hline \multicolumn{5}{|l|}{ Expenses } \\
\hline$\overline{R M 500-R M 1000 ~}$ & 38 & 23.0 & & \\
\hline RM1001-RM1500 & 58 & 35.2 & & \\
\hline RM1501-RM2000 & 36 & 21.8 & & \\
\hline >RM2000 & 33 & 20.0 & & \\
\hline Total & 165 & 100 & & \\
\hline
\end{tabular}

Based on table 1, shows the results of experimental participants profile for the study. For gender, 72.1 percent (119 people) consist of male and 21.9 percent (46 people) made up of female.

For the age, a total of 53.33 percent ( 88 people) consists of those aged between 30 to 39 years. 29.10 percent of them between the ages of 20 to 29 years with a total of 48 people. 13.33 per 
INTERNATIONAL JOURNAL OF ACADEMIC RESEARCH IN BUSINESS AND SOCIAL SCIENCES

Vol. 10, No. 15, Youth and Community Wellbeing: Issues, Challenges and Opportunities for Empowerment V1. 2020, E-ISSN: 2222-6990 @ 2020 HRMARS

cent ( 22 people) ranging from age 40 to 49 years. And the last is a participant aged 50 to 59 years at 4.24 per cent (7 people). Mean score for the age group was 33.67(S.D=7.82).

For the location category, descriptive analysis result showed 58.8 percent (97 people) of whom live in urban areas. While 41.2 per cent (68 people) resides in rural areas. Mean score for this category was $\mathrm{M}=1.45$ (S. $\mathrm{D}=0.546)$.

Descriptive analysis for the income, result showed 47.3 percent (78 people) with income between RM1501 to RM2500. While 30.9 percent (51 people) are those with income between RM900 to RM1500. 17.6 percent (20 people) have higher income than RM2500. The rest are those who have an income between RM500 to RM900 i.e. 4.2 percent (7 people). Mean score for the income group was $\mathrm{M}=\mathrm{RM} 2.78$ (S.D=0.781).

For the expenses, findings showed the highest total expenses was with the total RM1001 to RM1500, with percentage 35.2 percent (58 people), followed RM500 to RM1000 with percentage 23 percent (38 people), RM1501 to RM2000 with percentage 21.8 percent (36 people) and expenses more than RM2000 with the least percentage 20 percent (33 people). Mean score for total expenses is $M=2.39(S . D=1.051)$.

Table 2: Analysis of variance (ANOVA) pretest and posttest expression reaction (L1) towards GST news framing

\begin{tabular}{lccccc}
\hline $\begin{array}{c}\text { Expression } \\
\text { L1 }\end{array}$ & $\begin{array}{c}\text { Sum of } \\
\text { Squares }\end{array}$ & df & Ms & F & Sig. \\
\hline $\begin{array}{l}\text { Between } \\
\text { Group }\end{array}$ & 86.196 & 9 & 9.577 & 2.294 & .05 \\
Within & 87.675 & 21 & 4.175 & & \\
Group & & & & & \\
Total & 173.871 & 30 & & & \\
\hline
\end{tabular}

Table 3: Analysis of variance (ANOVA) pre test and post test expression reaction (L2) towards GST news framing

\begin{tabular}{lccccc}
\hline $\begin{array}{c}\text { Expression } \\
\text { L2 }\end{array}$ & $\begin{array}{c}\text { Sum of } \\
\text { Squares }\end{array}$ & df & Ms & F & Sig. \\
\hline $\begin{array}{l}\text { Between } \\
\text { Group }\end{array}$ & 74.000 & 9 & 8.222 & 3.321 & .01 \\
Within & 52.000 & 21 & 2.476 & & \\
Group & & 30 & & & \\
Total & 126.000 & 30 & & & \\
\hline
\end{tabular}


INTERNATIONAL JOURNAL OF ACADEMIC RESEARCH IN BUSINESS AND SOCIAL SCIENCES

Vol. 10, No. 15, Youth and Community Wellbeing: Issues, Challenges and Opportunities for Empowerment V1. 2020, E-ISSN: 2222-6990 @ 2020 HRMARS

Table 4: Analysis of variance (ANOVA) pre test and post test expression reaction (L3) towards GST news framing

\begin{tabular}{lccccc}
\hline $\begin{array}{c}\text { Expression } \\
\text { L3 }\end{array}$ & $\begin{array}{c}\text { Sum of } \\
\text { Squares }\end{array}$ & df & Ms & F & Sig. \\
\hline $\begin{array}{l}\text { Between } \\
\text { Group }\end{array}$ & 67.544 & 9 & 7.505 & 1.011 & .46 \\
Within & 155.875 & 21 & 7.423 & & \\
Group & & & & & \\
Total & 223.419 & 30 & & & \\
\hline
\end{tabular}

Table 5: Analysis of variance (ANOVA) pre test and post test expression reaction (L4) towards GST news framing

\begin{tabular}{lccccc}
\hline $\begin{array}{c}\text { Expression } \\
\text { L4 }\end{array}$ & $\begin{array}{c}\text { Sum of } \\
\text { Squares }\end{array}$ & df & Ms & F & Sig. \\
\hline $\begin{array}{l}\text { Between } \\
\text { Group }\end{array}$ & 68.709 & 9 & 7.634 & 1.265 & .31 \\
Within & 126.775 & 21 & 6.037 & & \\
Group & & & & & \\
Total & 195.484 & 30 & & & \\
\hline
\end{tabular}

Table 6: Analysis of variance (ANOVA) pre-test and post-test expression reaction (L5) towards GST news framing

\begin{tabular}{lccccc}
\hline $\begin{array}{c}\text { Expression } \\
\text { L5 }\end{array}$ & $\begin{array}{c}\text { Sum of } \\
\text { Squares }\end{array}$ & df & Ms & F & Sig. \\
\hline $\begin{array}{l}\text { Between } \\
\text { Group }\end{array}$ & 74.867 & 9 & 8.319 & 1.258 & .31 \\
Within & 138.875 & 21 & 6.613 & & \\
Group & & & & & \\
Total & 213.742 & 30 & & & \\
\hline
\end{tabular}

Table 7: Analysis of variance (ANOVA) pre-test and post-test expression reaction (L6) towards GST news framing

\begin{tabular}{lccccc}
\hline $\begin{array}{c}\text { Expression } \\
\text { L6 }\end{array}$ & $\begin{array}{c}\text { Sum of } \\
\text { Squares }\end{array}$ & Df & Ms & F & Sig. \\
\hline Between & 72.896 & 9 & 8.100 & .940 & .51 \\
Group & & & & & \\
Within Group & 180.975 & 21 & 8.618 & & \\
Total & 253.871 & 30 & & & \\
\hline
\end{tabular}


INTERNATIONAL JOURNAL OF ACADEMIC RESEARCH IN BUSINESS AND SOCIAL SCIENCES

Vol. 10, No. 15, Youth and Community Wellbeing: Issues, Challenges and Opportunities for Empowerment V1. 2020, E-ISSN: 2222-6990 @ 2020 HRMARS

Table 8: Analysis of variance (ANOVA) pretest and posttest expression reaction (L7) towards GST news framing

\begin{tabular}{lccccc}
\hline $\begin{array}{c}\text { Expression } \\
\text { L7 }\end{array}$ & $\begin{array}{c}\text { Sum of } \\
\text { Squares }\end{array}$ & Df & Ms & F & Sig. \\
\hline $\begin{array}{l}\text { Between } \\
\text { Group }\end{array}$ & 78.288 & 9 & 8.699 & 1.095 & .40 \\
Within & 166.808 & 21 & 7.943 & & \\
Group & & & & & \\
Total & 245.097 & 30 & & & \\
\hline
\end{tabular}

According to the table 2 and 3, showed that a significant difference to both level (L1 and L2) of expression with a value obtained respectively are $F(9,21, p<0.05)=2,294$ and $F(9,21, p<0.05)=$ 3,321 . Both level of expression participant is not equal between the pre and posttest. With the exactly explanation, the participant of experiment reacts or give a responses of expression on this both level.

While for table 4,5,6,7 and 8 also showed that there is no significant difference for level 3 to 7 with the values were each $F(9,21, p>0.05)=1,011, F(9,21, p>0.05)=1.265, F(9,21, p>0.05)=1.258$, $F(9.2, p>0.05)=0.940, F(9,21, p>0.05)=1.095$. These situations showed for the level 3 through 7 of expression are different between pre and posttest. It is also explained that, participant of experimental did not express any reaction for 5 level of expression.

\section{Discussion and Conclusion}

For the first and second objective in this study, which is to identify and test the effect of GST news framing toward public expression, test of Analysis of Variances (ANOVA) used to measure whether there is a differences before and after these (pro,anti and neutral) frames displayed. The results show that based on the seven levels of expression adopted from the study of Boyle et al. (2006) showed that the Malaysian only respond at the first and second level of expression $(p<0.05)$. It's for very minimum level which is discuss with the family and heard on issues to others. While for the other five level showed that are not response $(p>0.05)$ for the more extreme level.

Contrary with findings from Boyle et al. (2006), individual whose support on certain issues will more express their reaction on group compare individual. And individual those not support on issues exposed by media more dominant to express their reaction through individual compare on group.

Terms of democracy or freedom of expression is a principle that always held by Malaysians. The same situation also occurs when the government implemented or changes of policy. Social media became as a shortcut to the government to introduce their new policy. Also the society used this platform to express their discontent or acceptance.

Justification for this study findings can be summed up into two factors. First, the participants involved in this experiment was the government server and they still under responsibility of the Federal Government. Critically, this group can't involve any illegal matter that affect the organization and the government directly. Contrary situation in Western, they voice out their expression on dissatisfaction issues compared to Malaysian society. Secondly is culture differences. Malaysian society is more concern to peaceful either violence environment. Therefore, they less tendency to express their reaction at extreme level. 
However, the findings obtained a new question theoretically, which is the actual effectiveness of news framing among Malaysian individually. As two factors discussed above is constraints to measure the effectiveness news framing not only on GST issue but also for other issues. Factors of democracy has been questioned, how a country practicing democracy or freedom of expression through the mass media and so on but practically is not implemented. The increasing use of the Internet for social networking, blogging, video-sharing, and tweeting fosters political participation. The decentralization of media alone leads to a reduction in the distance between the various actors of political communication, thus making the traditional division of roles between actors in and around the political system less distinct. Politicians and journalists are no longer the sole producers of political information (Tobias, 2019)

This situation is actually not only discussed in Malaysia but also in Western countries, by master Van Aelst et al. (2017) explaining to ensure the effectiveness of the principle of freedom of expression in a democratic system, it is It is very important to ensure that laws protect every individual rights. Speak about democracy not only refers to the institutions, but democracy involves the process of finding the right to ensure that every community have the opportunity to involve themselves in politics, to convey their opinions and influencing decision making on politics. As a way to ensure and guarantee their interest.

However, through a study conducted there is limitations identified and need to be run through framing effects studies in the future. This research only tested on response expression from government server under state government. For the future, attention should be extending for the different community groups. This is because the effects of framing differences based on individual schemata. The background of the participant also produces different framing effects. Thus, contribute the different perspective to the study of framing as a whole.

\section{References}

Hussain, A. A. (2000). Analisis Dasar Awam: Peranan Kerajaan Mengatasi Masalah Ekonomi Dalam Sistem Pasaran Bebas. Kuala Lumpur: Utusan Publications \& Distributors Sdn Bhd.

Bennet, W. L. (2007). News the Politics of Ilusions. United State: The University of Chicago Press.

Boyle, M. P., Schmierbach, M., Amstrong, C. L., Cho, J., McCluskey, M., McLeod, D., \& Shah, D. V. (2006). Expressive responses to news stories about extremist group: a framing experiment. Journal of Communication, 56, 271-288.

Burgoon, M. (1989). Message and persuasive. Theory and research on mental models of messages. DIm. Bradac, J.J. (ed.). London, Sage Publications. Message. Effects in Communication Science, 10-23.

Cartee, K. S. J. (2005). News Narratives and News Framing. Lanham: Rowman \& Littlefield Publisher. Cook, T. (2007). Governing with the news, the news media as political institution. In. Negrine, R., \& Stanyer, J. (ed.). The Political Communication Reader. London: Routledge Taylor and Francis Group.

De Vreese, C. H. (2005). News framing: Theory and typology. Information Design Journal+ Document Design, 13(1), 51-62.

Gamson, W. A., \& Modigliani. (1989). Media discourse and public opinion on nuclear power: A constructionist approach. American Journal of Sociology, 95(1), 1-37. 
Klar, S., Robison, J., \& Druckman, J.N. (2013). Political dynamics of framing. In. Ridout, T.N. (ed.). News Directions in Media \& Politics, 173-187. London: Taylor Francis Group.

McClure, J., White, J., \& Sibley, C.G. (2009). Framing effects on preparation intentions: Distinguishing action and outcomes. Disaster Prevention and Management 18: McQuail, D. 1994. Mass Communication Theory. London: Sage Publication.

Idris, N. A. H., \& Yussof, I. (2009). Ekonomi Malaysia Ke Arah Pembangunan Seimbang. Bangi: Universiti Kebangsaan Malaysia.

Nadiah, N. S., \& Maheran, M. (2019). New media and political Participation in Malaysia: Impacts and Limitations. A Contemporary Business Journal, 8(1), 25-46.

Sanders, K. (2009). Communicating politics in the twenty-first century. New York: Palgrave Mcmillan.

Schenk, A., \& Oldman, O. (2007). Value Added Tax, A Comparative Approach. Cambridge: University Press.

Singaravelloo, K. (2013). Local government and intergovernmental relations. In. Siddiquee. Public Management and Governance in Malaysia. New York: Routledge.

Tobias, E. (2019). Introduction: Changing media- changing democracy? In. Relation (ed.) The Democratic of Social Media. Austrian Academy of Sciences Press: Austria.

Van Aelst, P., Stromback, J., Aalberg, T., Esser, F., de Vreese, C., Matthes, J., Hopmann, D., Salgado, S., Hube, N., Stepinkska, A., Papathanassopoulos, S., Berganza, R., Legnante, G., Reinemann, C., Sheafer, T., \& Stanyer, J. (2017). Political communication in a high-choice media environment: a challenge for democracy? Annals of the International Communication Association, 41(1), 3-27. 